\title{
GAMBARAN HISTOPATOLOGIK TESTIS MENCIT SWISS (MUS musculus) YANG DIBERI KEDELAI (Glycine max) DAN PAPARAN DENGAN ASAP ROKOK
}

\author{
${ }^{1}$ Felisia R. Hargono \\ ${ }^{2}$ Poppy M. Lintong \\ ${ }^{2}$ Carla F. Kairupan \\ ${ }^{1}$ Kandidat skripsi Fakultas Kedokteran Universitas Sam Ratulangi Manado \\ ${ }^{2}$ Staf pengajar Bagian Patologi Anatomi Fakultas Kedokteran \\ Universitas Sam Ratulangi Manado \\ Email: feli_go057@yahoo.co.id
}

\begin{abstract}
Background: Cigarettes contain Polynuclear Aromatic Hydrogen and nicotine which can interfere with the process of spermatogenesis. The activity of free radicals can be inhibited by isoflavone and the amino acid arginine contained in soybean seeds.Objective: To reveal the histopathological features of the testis of Swiss rats exposed to cigarette smoke and administered with soybean. Method: Experimental research employed nine rats which were divided into three groups. Rats in Group A were fed with standard pellet for 35 days (negative control). Rats in Group B were exposed to cigarette smoke and were fed with standard pellet for 35 days. Rats in Group C were exposed to cigarette smoke and were fed with soybean 5 gr/day for 35 days. Results: Features of tubulus seminiferus with layers of spermatogenic cells which is in accordance with normal developmental stages were revealed in Group A. Meanwhile, in Group B, features of tubulus seminiferus with loose and irregular layers of spermatogenic cells were seen. Tubular lumen contained less spermatocytes and spermatid than Group A, making the lumen looked bigger and filled with less spermatozoa. In Group C, features of tubulus seminiferus with spematogenic cells which were denser than Group B were revealed. Conclusions: Exposure to the smoke of 2 cigarettes/day cause a decrease in the number of spermatogenic cells of the tubulus seminiferus in rat's testis. The administration of soybean of $5 \mathrm{gr} / \mathrm{day}$ cause an increase in the number of spermatogenic cells of the tubulus seminiferus in rat's testis exposed to cigarette smoke.
\end{abstract}

Keywords: cigarette smoke, soybean, spermatogenic cell.

Abstrak: Latar Belakang: Rokok mengandung Polynuclear Aromatic Hydrogen dan nikotin yang dapat mengganggu proses spermatogenesis. Aktivitas radikal bebas dapat dihambat oleh isoflavon dan komponen asam amino arginin dalam biji kedelai. Tujuan: Untuk mengetahui gambaran histopatologis testis mencit swiss yang dipapar asap rokok dan diberikan kedelai. Metode: Penelitian eksperimental menggunakan 9 ekor mencit yang dibagi menjadi 3 kelompok. Kelompok A diberi pelet standar selama 35 hari (kontrol negatif). Kelompok B diberi perlakuan asap rokok dan pelet standar selama 35 hari. Kelompok C diberi perlakuan asap rokok dan makan pelet kedelai 5 gr/hari selama 35 hari. Hasil: Pada kelompok A didapatkan gambaran tubulus seminiferus dengan susunan lapisan sel spermatogenik sesuai tingkat perkembangan normal. Pada kelompok B didapatkan gambaran tubulus seminiferus dengan susunan sel spermatogenik yang longgar dan tidak teratur, lumen tubulus mengandung spermatosit dan spermatid yang lebih sedikit dibandingkan kelompok A sehingga lumen terlihat lebih besar dan tidak terisi penuh dengan spermatozoa. Pada kelompok C didapatkan gambaran tubulus seminiferus dengan sel spermatogenik yang lebih padat dibandingkan kelompok B. Simpulan: Pemaparan asap rokok 2 batang/hari menyebabkan berkurangnya 
jumlah sel-sel spermatogenik tubulus seminiferus testis mencit. Pemberian kedelai $5 \mathrm{gr} / \mathrm{hari}$ menambah jumlah sel-sel spermatogenik pada tubulus seminiferus testis mencit yang terpapar dengan asap rokok.

Kata Kunci: Asap rokok, kedelai, sel spermatogenik.

Rokok merupakan sumber utama radikal bebas yang berasal dari lingkungan. Saat ini kebanyakan masyarakat memiliki tingkat konsumsi rokok yang tinggi sehingga menyebabkan produksi asap rokok yang tinggi pula. Kebiasaan merokok ini dianggap dapat memberikan kenikmatan bagi si perokok. ${ }^{1}$ Dilain pihak, efek negatif asap rokok terhadap kesehatan sangat beragam, antara lain sebagai penyebab karsinoma paru, penyakit jantung koroner dan penyakit pembuluh darah lainnya, serta komplikasi pada kehamilan/janin. Efek lainnya yang sering diabaikan adalah gangguan pada sistem reproduksi. ${ }^{2}$

Rokok mengandung 4000 jenis bahan kimia dan sebagian besar bersifat toksik. ${ }^{3}$ Sekitar 100 senyawa yang bersifat toksik seperti bahan karsinogen, tar, nikotin, nitrosamin, karbonmonoksida, senyawa PAH (Polynuclear Aromatic Hydrogen), fenol, karbonil, klorindioksin, dan furan. Asap rokok mengandung radikal bebas yang sangat tinggi. Kandungan $\mathrm{PAH}$ dari rokok menyebabkan atrofi testis, menghambat spermatogenesis dan merusak morfologi spermatozoa. Nikotin dalam rokok menghambat sel Leydig dan menyebabkan penurunan kadar hormon testosteron. ${ }^{4}$

Aktifitas radikal bebas dapat dihambat oleh antioksidan. Salah satu antioksidan yaitu isoflavon yang terdapat dalam biji kedelai. Isoflavon kedelai disebut juga sebagai fitoestrogen, karena struktur kimianya hampir sama dengan estrogen. Terdapat empat bentuk isoflavon pada kedelai, yaitu (1) bentuk aglikon (bentuk bebas): genistein, daidzein, dan glisitein, (2) bentuk glikosida: genistin, daidzin, dan glisetin, (3) bentuk asetilglikosida, dan (4) bentuk malonilglikosida. Dosis kedelai dan isoflavon harus disesuaikan dengan dosis konsumsi isoflavon per hari yang disarankan oleh beberapa ahli yaitu 30-40 mg, ${ }^{5}$ karena konsumsi kedelai dan isoflavon yang tinggi dapat menurunkan konsentrasi sperma. ${ }^{6}$ Astuti (1999) ${ }^{7}$ menyatakan bahwa pada pemberian genistein yang merupakan bentuk aglikon dari isoflavon, melalui injeksi pada dosis 4 $\mathrm{mg} / \mathrm{kg}$ berat badan/hari dilaporkan perubahan pada berat testis, serta berkurangnya volume lumen pada tubuli seminiferus dan terganggunya spermatogenesis.

Selain isoflavon, dalam biji kedelai juga terkandung komponen asam amino arginin yang dapat meningkatkan kadar hormon testosteron. ${ }^{8}$ Hormon testosteron penting bagi pertumbuhan dan pembelahan sel-sel germinal sehingga proses spermatogenesis akan berjalan lebih baik dan jumlah sperma akan meningkat. Hal ini mendorong peneliti untuk melihat pengaruh kedelai terhadap histopatologi testis mencit setelah paparan dengan asap rokok.

\section{METODE PENELITIAN}

Penelitian ini merupakan penelitian eksperimental laboratorik, dilakukan pada periode Oktober 2012-Januari 2013 di Laboratorium Patologi Anatomi Fakultas Kedokteran Universitas Sam Ratulangi, Manado. Penelitian menggunakan 9 ekor mencit spesies mus musculus, jantan, berumur 3-4 bulan dengan berat rata-rata 25 gram, yang dibagi menjadi 3 kelompok, yaitu kelompok A yang diberi makan pelet standar selama 35 hari, kelompok B diberi asap rokok dan makan pelet standar selama 35 hari, dan kelompok $\mathrm{C}$ diberi asap rokok dan makan pelet kedelai secara bersamaan selama 35 hari. Ketiga kelompok diterminasi hari ke-36. Rokok yang digunakan yaitu rokok kretek merek DJI SAM SOE dengan kandungan $39 \mathrm{mg}$ tar dan 2,3 mg nikotin/batang. Dosis rokok yang digunakan sebanyak 2 batang rokok dibakar dan asapnya dipaparkan pada 2 kelompok mencit perlakuan selama 35 hari. 
Kedelai yang digunakan yaitu biji kedelai curah yang dibeli di pasar tradisional Manado. Dosis kedelai yang digunakan sebanyak $5 \mathrm{gr} /$ hari. Kedelai diolah menjadi pelet dan diberikan pada mencit secara oral.

Pemberian kedelai yang mengandung antioksidan diharapkan dapat meminimalisir kerusakan testis mencit yang disebabkan oleh paparan asap rokok. Kedelai diberikan secara oral untuk melihat efek antioksidan yang terkandung di dalamnya terhadap gambaran histopatologis jaringan testis dari mencit yang dipapar asap rokok. Gambaran histopatologis testis yang dievaluasi adalah lapisan sel spermatogenik mulai dari spermatogonia sampai spermatozoon.

Untuk proses pemaparan asap rokok, hewan uji diletakkan di dalam kandang, yaitu suatu kotak tertutup yang diberi celah untuk pertukaran udara. Rokok yang telah dinyalakan kemudian diletakkan pada bagian dasar kotak. Asap rokok naik memenuhi kotak sehingga mencit yang berada dalam kotak terpapar dengan asap rokok. Dalam hal ini mencit berperan sebagai perokok pasif. Satu batang rokok memerlukan waktu \pm 30 menit untuk habis terbakar. Jadi, untuk percobaan ini diperlukan waktu sekitar 40 menit/hari untuk pemaparan mencit dengan asap rokok.

\section{HASIL PENELITIAN}

\section{Gambaran makroskopik}

Gambaran makroskopik testis kelompok perlakuan memperlihatkan warna yang lebih pucat dibandingkan dengan kelompok kontrol. Konsistensi testis, semuanya sama yaitu kenyal sedangkan berat dan ukuran bervariasi antara satu kelompok dengan kelompok lainnya namun relatif sama (Tabel 1).

\section{Kelompok A}

Kelompok A (kontrol negatif) didapatkan gambaran testis yang normal. Pada sediaan testis ini tampak tubulus seminiferus dengan susunan lapisan sel spermatogenik yang normal. Sel spermatogenik tersusun berlapis sesuai dengan tingkat perkembangannya dari membran basalis menuju ke arah lumen tubulus yakni spermatogonia, spermatosit, spermatid sampai spermatozoon (gambar 1).

Tabel 1. Gambaran makroskopik testis mencit

\begin{tabular}{cccccccc}
\hline \multicolumn{2}{l}{ Kelompok hewan uji } & Warna & Konsistensi & $\begin{array}{c}\text { Berat } \\
\text { (gr) }\end{array}$ & $\begin{array}{c}\text { Panjang } \\
(\mathbf{c m})\end{array}$ & $\begin{array}{c}\text { Lebar } \\
(\mathbf{c m})\end{array}$ & $\begin{array}{c}\text { Tebal } \\
(\mathbf{c m})\end{array}$ \\
\hline Kontrol & A1 & Merah kecokelatan & Kenyal & 0,12 & 0,8 & 0,5 & 0,5 \\
negatif & A2 & Merah kecokelatan & Kenyal & 0,11 & 0,7 & 0,6 & 0,5 \\
& A3 & Merah kecokelatan & Kenyal & 0,11 & 0,6 & 0,5 & 0,5 \\
\hline Asap & B1 & Merah muda & Kenyal & 0,05 & 0,7 & 0,5 & 0,5 \\
rokok & B2 & Merah muda & Kenyal & 0,02 & 0,6 & 0,4 & 0,4 \\
& B3 & Merah muda & Kenyal & 0,02 & 0,7 & 0,4 & 0,4 \\
\hline $\begin{array}{c}\text { Asap } \\
\text { rokok }\end{array}$ & C1 & Merah kekuningan & Kenyal & 0,04 & 0,5 & 0,4 & 0,4 \\
$\begin{array}{c}\text { dan } \\
\text { kedelai }\end{array}$ & C3 & Merah kekuningan & Kenyal & 0,04 & 0,5 & 0,4 & 0,3 \\
\hline
\end{tabular}




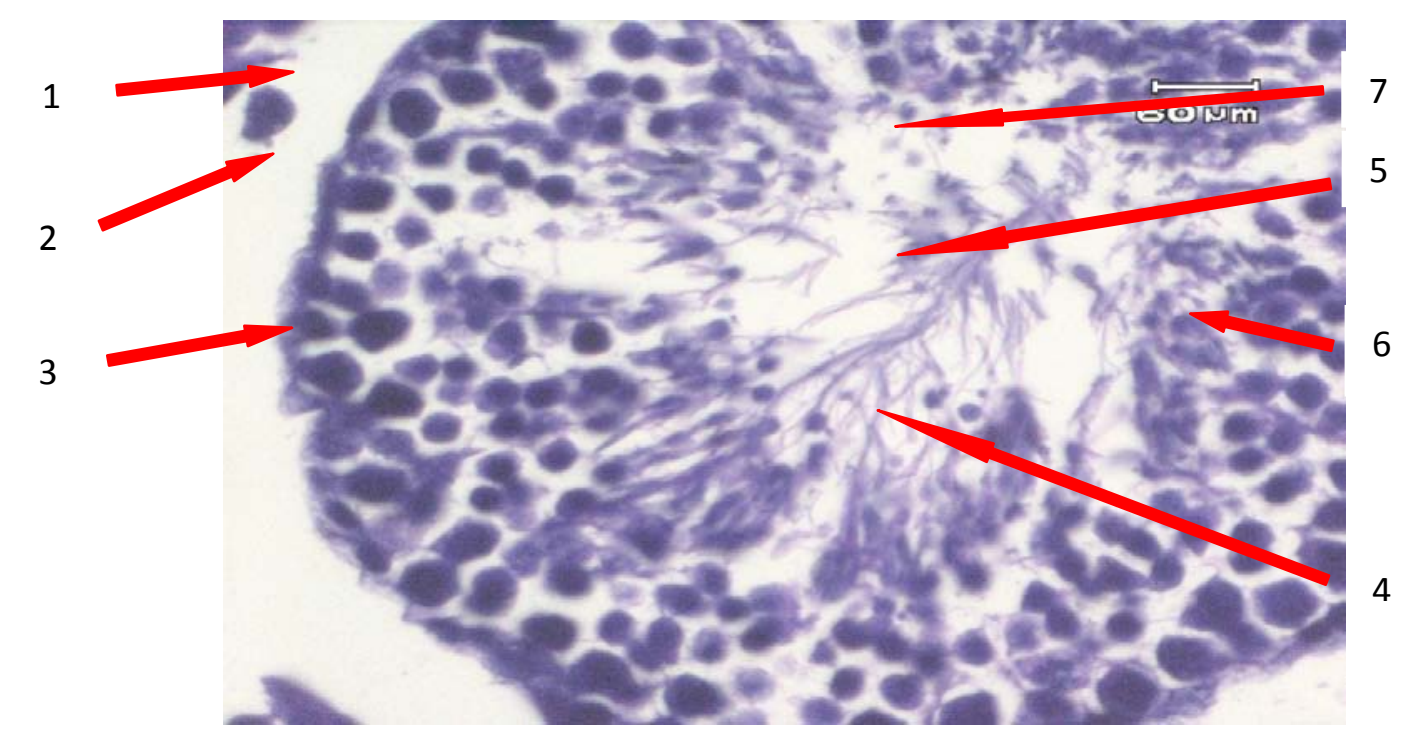

Gambar 1. Gambaran mikroskopik salah satu tubulus seminiferus testis mencit kelompok A (kontrol negatif). Terlihat tubulus seminiferus dengan lapisan sel spermatogenik yang normal, yaitu membran basalis (1), spermatogonium (2), spermatosit (3), spermatid (4), spermatozoa (5). Tampak pula sel sertoli (6) dan lumen (7). Pembesaran 10x40.

\section{Kelompok B}

Kelompok B yang diberi perlakuan asap rokok didapatkan testis yang memiliki tubulus seminiferus dengan susunan sel spermatogenik yang longgar dan tidak teratur. Kepadatan spermatozoa di dalam lumen tubulus jelas berbeda dengan yang terlihat pada kelompok kontrol. Lumen tubulus mengandung spermatosit dan spermatid yang lebih sedikit sehingga lumen terlihat lebih besar dan tidak terisi penuh dengan speramatozoa (Gambar 2).

\section{Kelompok C}

Kelompok C merupakan kelompok mencit yang diberi perlakuan asap rokok dan kedelai. Pada kelompok mencit ini didapatkan testis yang memiliki tubulus

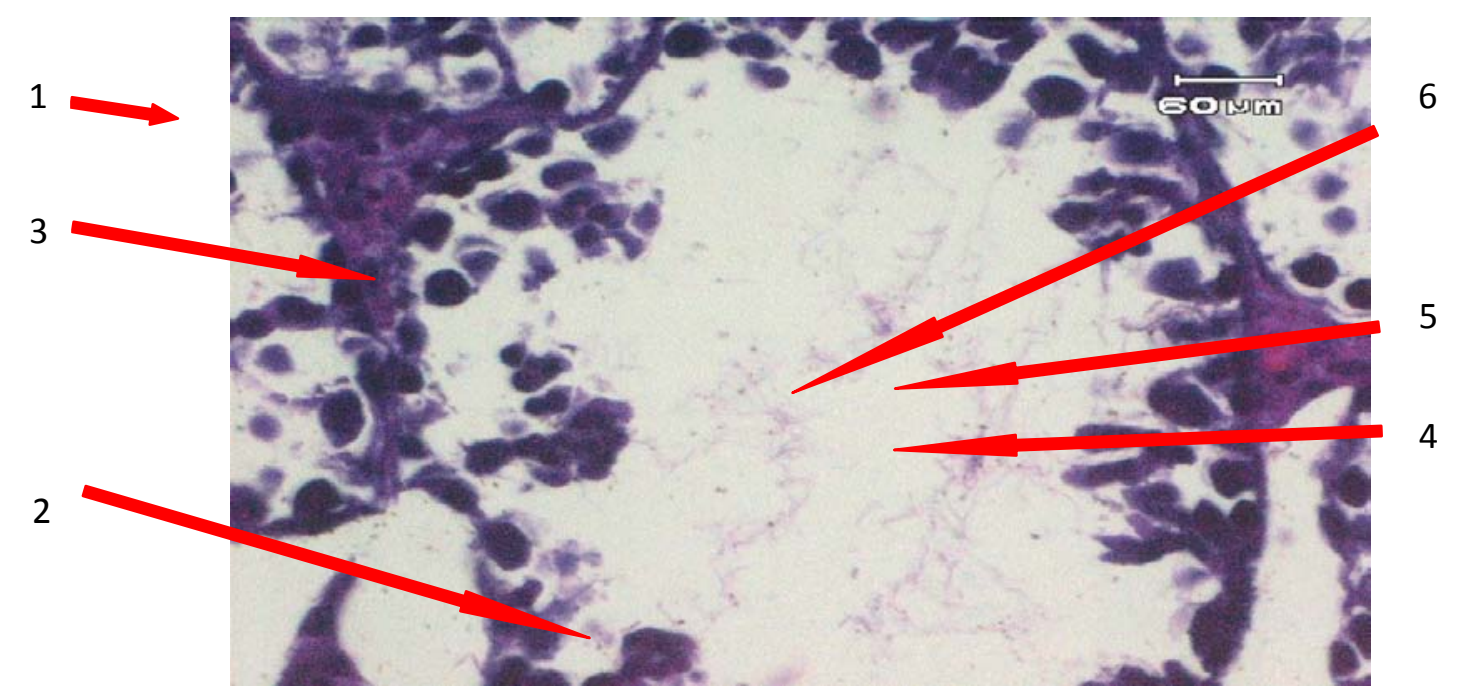

Gambar 2. Gambaran mikroskopik salah satu tubulus seminiferus testis mencit kelompok B (diberi perlakuan asap rokok). Tampak lapisan sel spermatogenik yang longgar dan tidak teratur. Membran basalis (1), Spermatogonium (2), Spermatosit (3), Spermatid (4), Spermatozoa (5), Lumen (6). Pembesaran 10x40. 
seminiferus dengan sel spermatogenik yang padat; lebih padat dibandingkan kelompok B (diberi perlakuan asap rokok), bahkan tampak sama dengan yang terlihat pada kelompok A (Gambar 3).

\section{BAHASAN}

Rokok merupakan sumber utama radikal bebas yang berasal dari lingkungan dan dapat menyebabkan gangguan pada sistem reproduksi. ${ }^{2}$ Sukmaningsih (2009) menyatakan bahwa kandungan nikotin dan $\mathrm{PAH}$ dalam asap rokok mempengaruhi kerja sistem saraf pusat dengan cara menghambat kerja GnRH sehingga rangsangan terhadap testis berkurang dan menyebabkan testis atrofi serta pembentukan FSH (Follicel Stimulating Hormone) dan LH (Luteinizing Hormone) terhambat. Terhambatnya pembentukan FSH dan LH menyebabkan proses spermatogenesis berlangsung tidak normal. Kedelai (Glycine max) mengandung isoflavon dan komponen asam amino arginin yang bekerja sebagai antioksidan untuk menangkal radikal bebas dan meningkatkan kadar hormon testosteron ${ }^{8}$ sehingga kerja dari GnRH dapat kembali normal dan proses spermatogenesis akan berjalan lebih baik. Penelitian yang telah dilakukan ini memberikan informasi tentang gambaran histopatologik mencit yang dipapar dengan asap rokok dan diberikan kedelai (Glycine max).

Penelitian ini membuktikan adanya peran paparan asap rokok terhadap abnormalitas spermatogenesis dalam tubulus seminiferus. Testis dari mencit yang diberi perlakuan asap rokok (kelompok B) memberikan gambaran berupa tubulus seminiferus dengan susunan sel spermatogenik yang longgar dan tidak teratur (gambar 2). Hasil ini ditunjang oleh data gambaran makroskopik dimana testis kelompok mencit ini relatif lebih ringan dibandingkan dengan kelompok kontrol negatif. Pada penelitian ini diduga terjadi penurunan hormon testosteron karena terhambatnya pembentukan FSH dan LH. Hormon testosteron diperlukan untuk memulai proses meiosis pada sel spermatosit. Bila spermatosit mengalami kerusakan maka akan mengalami degenerasi dan difagositosis oleh sel sertoli sehingga jumlah spermatosit menjadi berkurang dan jumlah spermatid juga ikut menurun. Selain itu, menurunnya hormon testosteron mengakibatkan terlepasnya sel spermatid dari sel sertoli ke lumen tubulus.

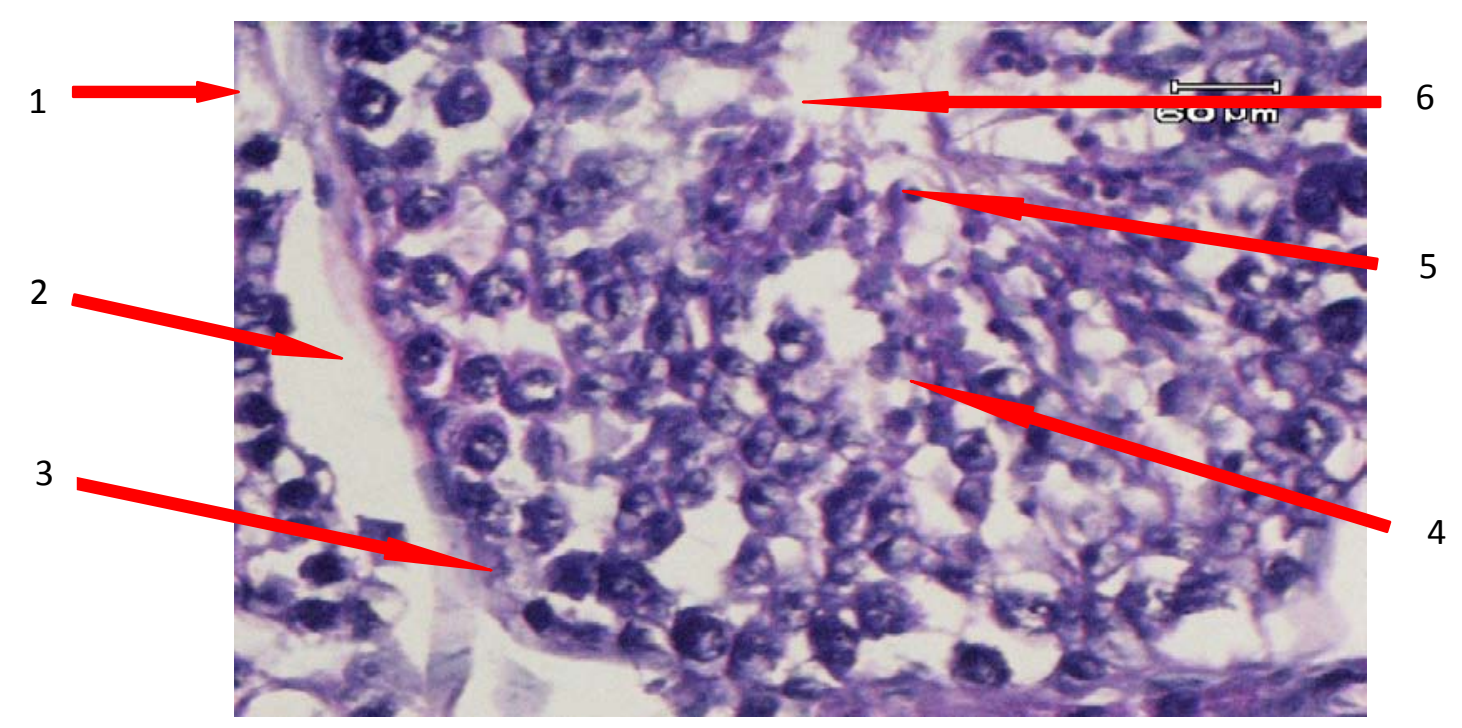

Gambar 3. Gambaran mikroskopik salah satu tubulus seminiferus testis mencit kelompok C (diberi perlakuan asap rokok dan kedelai). Terlihat tubulus seminiferus dengan lapisan sel spermatogenik yang lebih padat, yaitu Membran basalis (1), Spermatogonium (2), Spermatosit (3), Spermatid (4) dan Spermatozoa (5). Tampak pula lumen (6). Pembesaran 10x40. 
Hal ini mengakibatkan kegagalan tahap spermiogenesis, dimana spermatid gagal menjadi spermatozoa. ${ }^{4}$

Hasil yang berbeda ditemukan pada kelompok mencit yang diberi perlakuan asap rokok dan diberikan kedelai (kelompok C). Testis mencit dari kelompok ini relatif lebih berat dan susunan sel spermatogenik tubulus seminiferus lebih padat (gambar 3) dibandingkan dengan kelompok mencit yang dipapar asap rokok tetapi tidak diberikan kedelai (kelompok B). Padatnya sel spermatogenik kemungkinan besar berhubungan dengan kandungan isoflavon dan komponen asam amino arginin dalam kedelai yang bekerja sebagai antioksidan sehingga dapat meminimalkan gangguan spermatogenesis pada tubulus seminiferus akibat radikal bebas yang terkandung dalam asap rokok. ${ }^{8}$

\section{SIMPULAN}

Berdasarkan hasil penelitian ini dapat disimpulkan bahwa pemaparan dengan asap rokok yang berasal dari 2 batang rokok/hari menyebabkan penurunan susunan sel-sel spermatogenik tubulus seminiferus testis mencit. Pemberian kedelai dengan dosis $5 \mathrm{gr} / \mathrm{hari}$ menambah jumlah sel-sel spermatogenik pada tubulus seminiferus testis mencit yang terpapar dengan asap rokok.

\section{UCAPAN TERIMA KASIH}

Ucapan terima kasih kepada Dr. dr. Lidya Tendean, M.Repro, Sp.And dan dr. Lily Loho, Sp.PA (K), serta semua pihak yang secara langsung maupun tidak langsung yang telah memberi ide maupun gagasan kepada penulis sehingga penulis dapat menyelesaikan artikel ini.

\section{DAFTAR PUSTAKA}

1. Salawati T, Amalia R, editor. Perilaku Merokok di Kalangan Mahasiswa Universitas Muhammadiyah Semarang (Smoking Behaviour Among Students in UNIMUS). Prosiding Seminar Nasional UNIMUS; 2010.

2. Mayasari YR, Ratnaningsih T, Romi MM. Efek Pemberian Kedelai (Soya max) terhadap Jumlah Sperma Tikus Putih (Rattus norvegicus) yang Diasapi Rokok Putih. Jurnal Kedokteran Yarsi. 2005;13:273-80.

3. Budiman. Masalah Kesehatan Akibat Alkohol dan Merokok. Dalam: Sudoyo AW, Setiyohadi B, Alwi I, K Marcellus S, Setati S, editor. Buku Ajar Ilmu Penyakit Dalam (Edisi Kelima). Jakarta: InternaPublishing, 2009; p.87-8.

4. Sukmaningsih A.A.SG.A. Penurunan Jumlah Spermatosit Pakiten dan Spermatid Tubulus Seminiferus Testis pada Mencit (Mus musculus) yang Dipaparkan Asap Rokok. Jurnal Biologi. 2009;XII(2):31-5.

5. Astawan M. Sehat dengan Hidangan Kacang dan Biji-bijian. Jakarta: Penebar Swadaya, 2009; hal.43-4.

6. Chavarro JE, Toth TL, Sadio SM, Hauser R. Soy Food and Isoflavon Intake in Relation to Semen Quality Parameters Among Men from an Infertility clinic. Human Reproduction. 2008;23:258490.

7. Wahyuni RS. Pengaruh Isoflavon Kedelai terhadap Kadar Hormon Testoteron, Berat Testis, Diameter Tubulus Seminiferus dan Spermatogenesis Tikus Putih Jantan (Rattus norvegicus). Tesis [Published]. Padang: Fakultas Kedokteran Andalas, 2012.

8. Sumosardjuno S. 100 Kiat Sehat-Bugar Panjang Umur. Jakarta: PT BPK Gunung Mulia, 2010; p.78-9. 